\title{
REKAYASA LIMBAH CANGKANG PILLA AMPULLACEA SEBAGAI PENYARING AIR RUMAHAN DENGAN VARIASI KETEBALAN
}

\author{
Ahmad Dony Mutiara Bahtiar' ${ }^{1)}$, Riswan Eko Wahyu Susanto ${ }^{2)}$, Devina Rosa \\ Hendarti ${ }^{3)}$. \\ ${ }^{1,2,3)}$ Teknik Mesin, PSDKU Politeknik Negeri Malang Di Kediri \\ E-mail: ${ }^{1)}$ Adonbahtiar82@gmail.com
}

\begin{abstract}
Abstrak
Rekayasa cangkang keong sawah (Pilla Ampellacea) ini adalah upaya pemanfaaatan limbah cangkang keong sawah yang selama ini hanya dibuang begitu saja supaya mempunyai nilai lebih yang bermanfaat untuk masyarakat. Serta cangkang keong sawah mudah untuk diternakan dan hidup bebas di daerah tropis seperti di Indonesia. Penelitian ini mengusulkan sebuah gagasan baru menggunakan cangkah keoang sawah sebagai membrane penyaring air kran di perumahan untuk mengikat logam-logam yang berbahaya apabila dikonsumsi oleh manusia. Selain logam-logam yang berbahaya juga mengikat bakteri e-coli yang menyebabkan diare. Cangkang keong sawah tersebut dicuci dengan larutan asam asetat dan disikat sampai bersih. Kemudian di giling sampai berbentuk serbuk dan mengalami berbagai macam perlakuan sampai terbentuk membran saringan air. Dari hasil penelitian didapatkan membran yang efektif untuk menyaring air dari kran dilakukan variasi ketebalan membran yaitu 2,4,6,8 mm adalah membrane dengan ketebalan $8 \mathrm{~mm}$.
\end{abstract}

Kata Kunci: Cangkang, Membran, Keong Sawah

\begin{abstract}
Abstrack
The manipulation of field snail shells (Pilla Ampellacea) is an effort to utilize the waste of snail shells which have only been thrown away become increas it's benefit to the people's. As well as the field snail shells are easy to breed and live freely in tropical areas such as Indonesia. This study give a new idea to use the step of the paddy field as a membrane to filter tap water in housing to bind metals that are dangerous if consumed by humans. beside from the dangerous metals, it also binds to the e-coli bacteria which causes diarrhea. The shells of the snails were washed with a solution of acetic acid and scrubbed thoroughly. Then it is milled to form a powder and undergoes various treatments to form a water filter membrane. From the research results, it was found that the membrane which is effective for filtering water from the faucet is carried out by varying the membrane thickness, namely $2,4,6,8 \mathrm{~mm}$ is a membrane with a thickness of 8 mm.
\end{abstract}

Keyword : shell, membrane, field snail 


\section{PENDAHULUAN}

Cangkang Pilla Ampullacea hampir seluruhnya terdiri dari kalsium karbonat. Kalsium fosfat, silikat, magnesium karbonat, besidan zat organik lainnya membentuk sisa komposisi protein struktural, dan senyawa fosfor [1]. Pilla Ampullacea merupakan hewan moluska yang banyak dijumpai di persawahan dan populasinya meningkat dalam waktu relatif cepat. Pilla Ampullacea telah berubah status dari hama padi peliharaan menjadi hewan pemeliharaan [2]. Cangkang Pilla Ampullacea dapat dimanfaatkan sebagai biokomposit untuk menyaring air rumahan dalam bentuk membran seperti saringan yang manfaatnya untuk menyerap logam-logam dan bakteri yang terkandung di air. Air merupakan kebutuhan yang sangat mendasar bagi makhluk hidup terutama manusia. Air berperan penting dalam berbagai kegiatan manusia misalnya air untuk konsumsi, memasak, mencuci, sanitasi, transportasi dan sebagainya. Kebutuhan air yang sehat bebas dari logam dan bakteri berbahaya bagi tubuh manusia sangat dibutuhkan demi langsungan hidup

Berbagai macam bakteri yang terkandung di air dapat menimbulkan penyakit seperti diare dan berbagai jenis logam yang terkandung di air juga dapat menimbulkan penyakit kangker. Salah satu upaya yang dapat dilakukan untuk mengatasi permasalahan tersebut adalah menggunakan saringan dari bahan alami yang tidak berbahaya bagi kesehatan dan dapat mengikat bakteri dan logam berat di air.

Penulis tertarik untuk memanfaatkan cangkang Pilla Ampullacea sebagai penyaring air perumahan dan pengikat logam berat sehingga dilakukan penelitian pembuatan membrane dari cangkang Pilla Ampullacea dan aplikasinya sebagai saringan pada kran air perumahan. Dalam penelitian ini akan diamati apa pengaruh variasi ketebalan dan porositas membran cangkang Pilla Ampullacea terhadap $\mathrm{pH}$, kekeruhan, total zat padat terlarut dan kandungan logam berat dan bakteri pada air perumahan. Serta penelitian ini akan bertahap untuk tahun berikutnya mengetahui kekuatan mekanik lainya. 


\section{METODE PENELITIAN}

Penelitian ini menggunakan metode penelitian true eksperimental yaitu penelitian yang sesungguhnya dilaksanakan melalui percobaan, data didapat dari hasil eksperimen di lapangan dengan cara mengambil data secara langsung berdasarkan pengamatan atau observasi terhadap subjek penelitian [3].

Desain penelitian merupakan rancangan cara menganalisis data agar dapat dilaksanakan secara jelas, praktis, dan efisien sesuai dengan tujuan penelitian. Adapum langka-langkah penelitian ini disusun sebagai berikut:

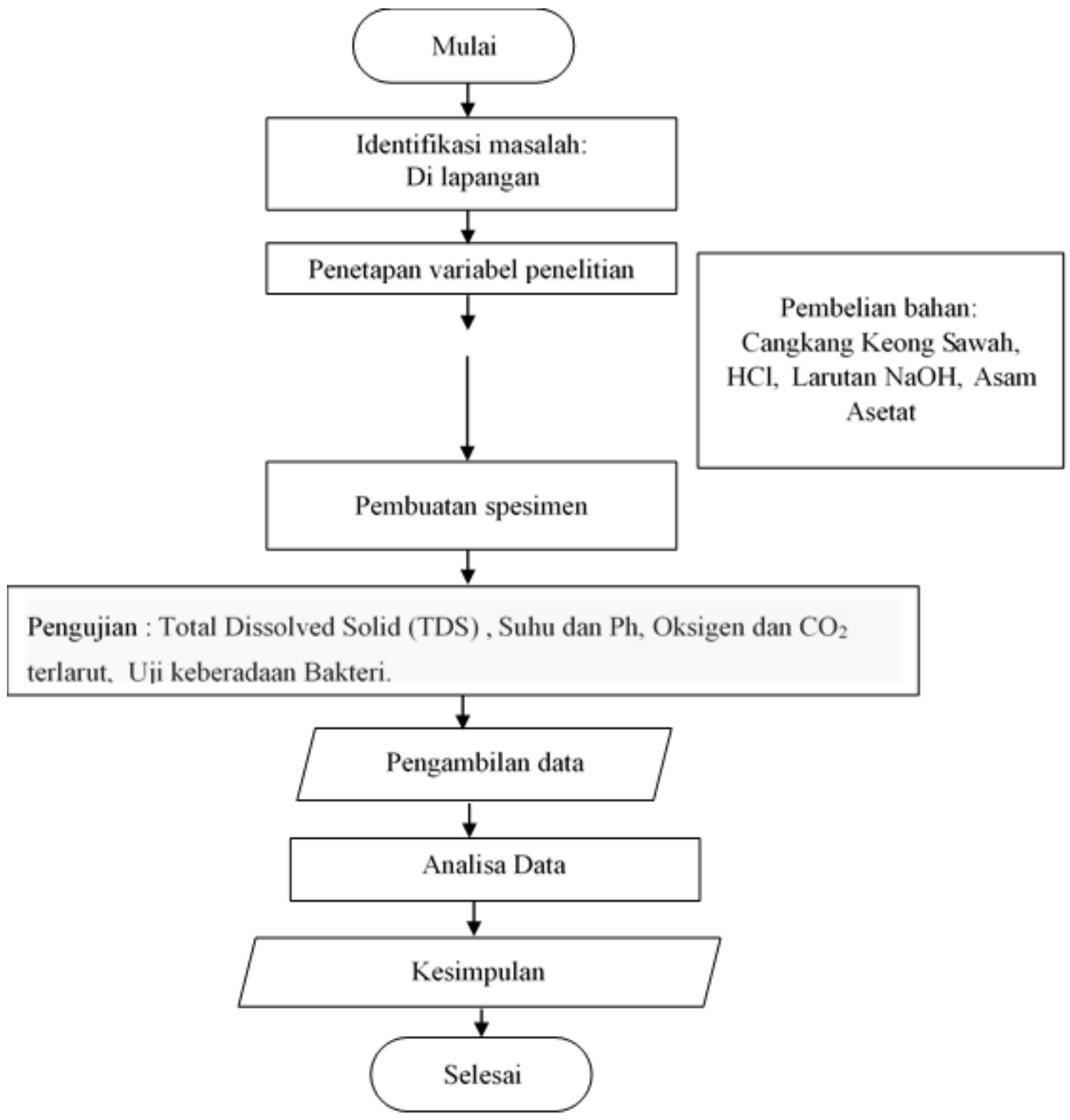

Gambar 1. Diagram alir penelitian 


\section{HASIL DAN PEMBAHASAN}

Cangkang Pilla Ampullacea harus dicuci dengan air bersih untuk menghilangkan kotoran dan sisa daging yang masih menempel pada pangkal cangkang. Kemudian cangkang dikeringkan di bawah sinar matahari untuk menghilangkan kandungan air dan memfasilitasi penyimpanan. Cangkang kering kemudian ditumbuk dan disaring menggunakan ayakan ukuran 100 mesh untuk memperluas area permukaan sehingga proses interaksi sampel dengan pelarut ketika isolasi kitosan lebih efektif. Tujuan dari tahap demineralisasi adalah untuk menghilangkan mineral atau senyawa anorganik yang terkandung dalam cangkang keong. Umumnya mineral yang ditemukan dalam cangkang keong adalah $\mathrm{CaCO} 3$ (kalsium karbonat) dan Ca3 (PO4) 2 (kalsium fosfat) [4]. Proses penghapusan dilakukan dengan mereaksikan bubuk shell dengan larutan 1,5 $\mathrm{M} \mathrm{HCl}$ pada suhu 60-70 oC sambil disterilkan selama 4 jam. Reaksi yang terjadi adalah sebagai berikut [5]:

$$
\begin{aligned}
& \mathrm{CaCO} 3(\mathrm{~s})+2 \mathrm{HCl}(\mathrm{aq}) \rightarrow \mathrm{CaCl} 2(\mathrm{aq})+\mathrm{H} 2 \mathrm{O}(\mathrm{l})+\mathrm{CO} 2(\mathrm{~g}) \\
& \mathrm{Ca} 3(\mathrm{PO} 4) 2(\mathrm{~s})+4 \mathrm{HCl}(\mathrm{aq}) \rightarrow 2 \mathrm{CaCl} 2(\mathrm{aq})+\mathrm{Ca}(\mathrm{H} 2 \mathrm{PO} 4) 2(\mathrm{l})
\end{aligned}
$$

Menurut reaksi di atas, gas $\mathrm{CO} 2$ yang terbentuk dapat dilihat dengan adanya gelembung dalam proses demineralisasi. Hasil reaksi demineralisasi ini membentuk kitin mentah yang berwarna coklat atau kuning muda

Pada fase deproteinisasi, akan terjadi pemutusan ikatan antara protein dan kitin sehingga warnanya berubah menjadi kuning kecoklatan. Tahap deasetilasi menggunakan $50 \% \mathrm{NaOH}$ solusi yang berfungsi untuk memutuskan ikatan karboksil dengan atom nitrogen dalam kitin. Konsentrasi $\mathrm{NaOH}$ yang tinggi menyebabkan gugus fungsi amino $(-\mathrm{NH} 3+)$ yang menggantikan gugus kitin kitin menjadi lebih aktif sehingga proses deasetilasi menjadi lebih baik. Mekanisme reaksi yang terjadi adalah sebagai berikut [6]:

$$
\begin{gathered}
\mathrm{CaCO} 3(\mathrm{~s})+2 \mathrm{HCl}(\mathrm{aq}) \rightarrow \mathrm{CaCl}_{2}(\mathrm{aq})+\mathrm{H} 2 \mathrm{O}(\mathrm{l})+\mathrm{CO} 2(\mathrm{~g}) \\
\mathrm{Ca} 3(\mathrm{PO} 4) 2(\mathrm{~s})+4 \mathrm{HCl}(\mathrm{aq}) \rightarrow 2 \mathrm{CaCl} 2(\mathrm{aq})+\mathrm{Ca}\left(\mathrm{H}_{2} \mathrm{PO} 4\right) 2(\mathrm{l})
\end{gathered}
$$


Menurut reaksi di atas, gas $\mathrm{CO} 2$ yang terbentuk dapat dilihat dengan adanya gelembung dalam proses demineralisasi. Hasil reaksi demineralisasi ini membentuk kitin mentah yang berwarna coklat atau kuning muda. Pada fase deproteinisasi, akan terjadi pemutusan ikatan antara protein dan kitin sehingga warnanya berubah menjadi kuning kecoklatan. Tahap deasetilasi menggunakan $50 \% \mathrm{NaOH}$ solusi yang berfungsi untuk memutuskan ikatan karboksil dengan atom nitrogen dalam kitin.

Analisis membran komposit Chitosan-PVA Membran yang telah dibuat digunakan untuk menyaring sampel air yang diambil dari sumur yang dibangun 10 meter dari sungai. Jarak 10 meter adalah persyaratan jarak minimum yang diizinkan untuk membangun gedung di sekitar sungai. Menurut Waluyo jaraknya ideal untuk meminimalkan kontaminasi. Kondisi sumber air sumur terlalu dekat dengan badan air sungai, memungkinkan air sumur untuk diisi ulang dari sungai yang tercemar dan mengurangi kualitas air

Hasil pengukuran parameter kualitas air sebelum disaring dan setelah melewati membran disajikan pada. Hasil untuk setiap ketebalan membran tampak berbeda. Perbedaan hasil mendukung pengaruh membran tebal pada kualitas air. Semakin tebal membran, semakin baik kualitas airnya. Parameter suhu, TDS, CO2 terlarut, TPC, dan E.coli MPN mengalami penurunan nilai seiring dengan meningkatnya ketebalan membran. DO dan pH meningkat mengikuti ketebalan. Temperatur tidak berubah terlalu jauh dan ketebalan tidak berpengaruh signifikan. Untuk persyaratan kebersihan sanitasi dengan kisaran $25-27^{\circ} \mathrm{C}$ adalah normal.

Tabel 1. Hasil Pengujian Air yang Sudah di Saring dengan Membran Pilla Ampullacea .

\begin{tabular}{|c|c|c|c|c|c|}
\hline \multirow[t]{2}{*}{ Parameter } & \multicolumn{3}{|c|}{ Tebal Membran (mm) } & \multirow[b]{2}{*}{8} & \multirow{2}{*}{$\begin{array}{l}\text { SNI } \\
\text { Standart }\end{array}$} \\
\hline & 2 & 4 & 6 & & \\
\hline Temperature $\left({ }^{\circ} \mathrm{C}\right)$ & 27 & 25 & 25 & 25 & Air temp \pm 3 \\
\hline $\begin{array}{l}\text { TDS }(\mathrm{mg} / \mathrm{L}) \\
\text { pH } \\
\text { DO (ppm) } \\
\text { Dissolved } \\
\text { CO2 (ppm) }\end{array}$ & $\begin{array}{l}500 \\
7,3 \\
1,7 \\
0,85\end{array}$ & $\begin{array}{l}420 \\
7,3 \\
2,5 \\
0,72\end{array}$ & $\begin{array}{l}400 \\
7,4 \\
4,8 \\
0,34\end{array}$ & $\begin{array}{c}200 \\
7,8 \\
6,4 \\
0,25\end{array}$ & $\begin{array}{l}1000 \\
6,5-8,5 \\
-\end{array}$ \\
\hline $\mathrm{TPC}(\mathrm{CFU} / \mathrm{ml})$ & $\begin{array}{c}5,3 x \\
10^{4}\end{array}$ & $\begin{array}{l}5,1 \mathrm{x} \\
10^{4}\end{array}$ & $\begin{array}{c}3,8 \mathrm{x} \\
10^{4}\end{array}$ & $\begin{array}{l}1,5 \mathrm{x} \\
10^{4}\end{array}$ & - \\
\hline MPN E.coli & 350 & 110 & 4 & 0 & 0 \\
\hline
\end{tabular}


Berdasarkan tabel diatas hasil pengukuran parameter kualitas air sebelum disaring dan setelah melewati membran disajikan pada Tabel diatas. Hasil untuk setiap ketebalan membran tampak berbeda. Perbedaan hasil mendukung pengaruh membran tebal pada kualitas air. Semakin tebal membran, semakin baik kualitas airnya.

\section{KESIMPULAN}

Membran yang dimodifikasi kitosan Pila ampullacea dan PVA memiliki kemampuan untuk menyaring air. Kualitas air yang telah bersentuhan dengan membran telah meningkatkan kualitas dan memenuhi persyaratan PERMENKES No. 322017 dalam memberikan kebersihan sanitasi. Semakin tebal semakin efektif untuk mengurangi total bakteri, jumlah E. coli dan melarutkan CO2 sementara DO meningkat

\section{DAFTAR PUSTAKA}

[1] H. Delvita, D. Djamas and Ramli, "PENGARUH VARIASI TEMPERATUR KALSINASI TERHADAP KARAKTERISTIK KALSIUM KARBONAT (CaCO3) DALAM CANGKANG KEONG SAWAH (Pila ampullacea) YANG TERDAPAT DI KABUPATEN PASAMAN," PILLAR OF PHYSICS, pp. 17-24, Oktober 2015.

[2] R. M. Marwoto, "A preliminary study of the biodiversity of the freshwater snail family Thiaridae from Indonesia (Mollusca: Prosobranchia)," in Tropical biodiversity and systematics, H. Ulrich, 1997.

[3] Sugiyono, Metode Penelitian Kuantitatif, Kualitatif, dan R\&D, Bandung: CV. Alfabeta, 2017.

[4] Edrizal, E. Desnita and L. G. Surya, "Pengaruh Cangkang Keong Sawah (Pila ampullacea) Terhadap Pembentukan Tulang Baru (Remodeling Tulang)," Heme, vol. II, no. 2, 2020. 
[5] Vogel, Buku Teks Analisis Anorganik Kualitatif Makro dan Semimikro. Edisi 5. Bagian 1., Jakarta: PT. Kalman Pustaka, 1985.

[6] T. Masindi and N. Herdyastuti, "KARAKTERISASI KITOSAN DARI CANGKANG KERANG DARAH (Anadara granosa)," Journal of Chemistry, vol. 6, no. 3, 2017. 